\title{
EFFECT OF STEEL FRAMING FOR SECURING DRYWALL PANELS ON THERMAL AND HUMIDITY PARAMETERS OF THE OUTER WALLS
}

\author{
Maciej MAJOR ${ }^{1,{ }^{*}}$, Mariusz KOSIŃ ${ }^{1}$ \\ ${ }^{1}$ Faculty of Civil Engineering, Czestochowa University of Technology, Akademicka 3, \\ 42-200 Częstochowa, Poland. \\ corresponding author: mmajor@bud.pcz.czest.pl
}

\section{Keywords:}

Light steel framing;

Thermal and humidity parameter;

Linear bridge;

Finite element method.

\section{Introduction}

Fixation of drywall panels to framing studs is more labour-consuming compared to gluing. In the case of framing, gluing panels is impossible. Therefore, they can be only secured directly to the loadcarrying partition wall or a framing. The building technology of framing construction has been described in [1]. The space between the studs can be filled with mineral wool which additionally improves thermal insulation of the interior and can serve as a soundproofing layer. It should be noted that linear thermal bridges can be formed near the locations of steel sections of the framing [2, 3].

Presence of thermal bridges is connected with accelerated heat transfer to the outside, leading to higher heat loss in the building, which consequently generates increased functional costs. Furthermore, there is a risk of vapour condensation on the internal part of the wall, leading to various destructive processes $[4,5]$.

\section{Characterization of the walls adopted for the thermal analysis}

The aim of the study was to determine and compare the profile of thermal insulation properties in a corner of the framing of an outer wall at the interior side finished with drywall fixed to the framing studs. The likelihood of water vapour condensation and mildew growth on the internal side of the wall was also evaluated. 


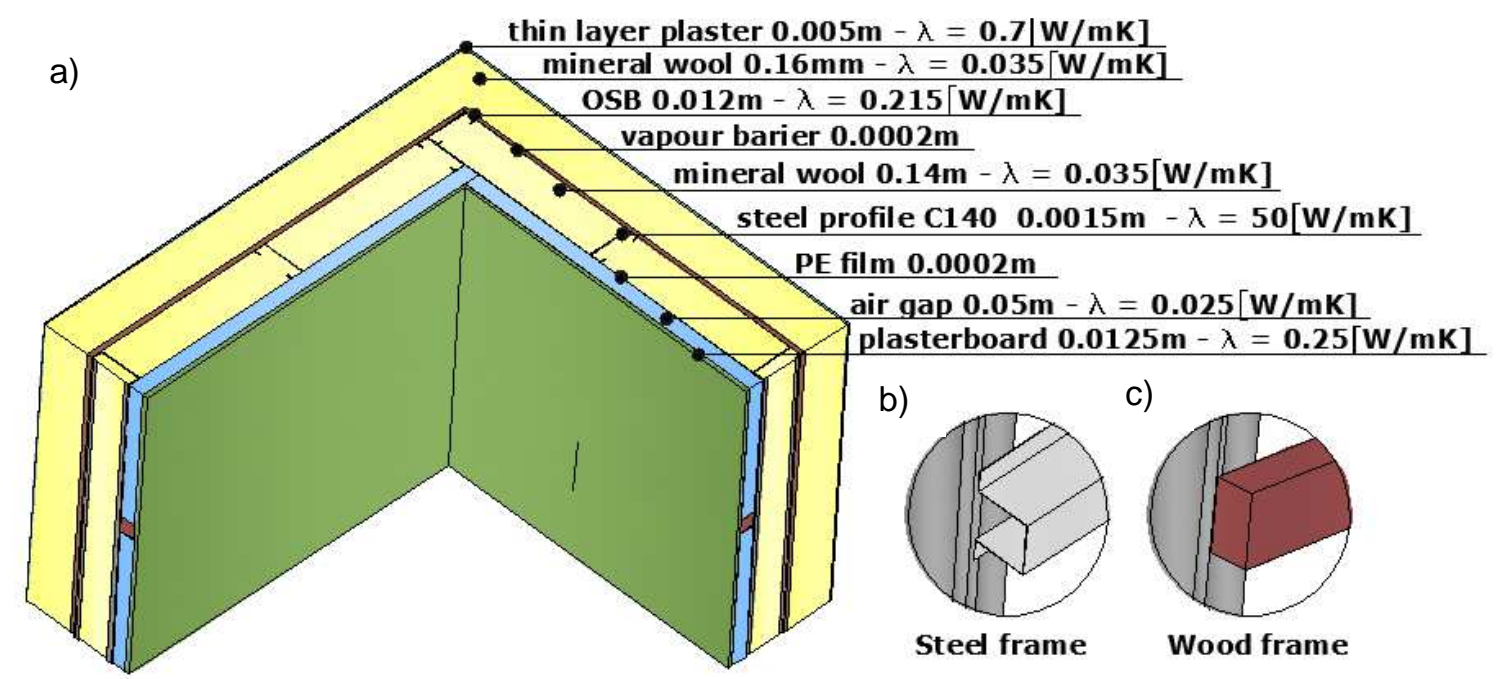

Fig. 1: The computational model for the analysed walls: a) type of material and thermal transfer coefficients, b) steel framing, c) wood framing.

The scope of the study included the analysis using the FEM method for the vertical wall made of thin-wall sections at the internal side, with drywall panels fixed to:

- steel sections,

- wood studs.

The material characterization for the analysed solutions of the corners of the external wall is presented in Fig. 1. Due to the insignificant effect, the data concerning vapour-permeable membrane and vapour-barrier membrane were neglected.

\section{Computational assumptions}

Using the algorithm below through computer simulation, the thermal transmittance $U\left[\mathrm{~W} /\left(\mathrm{m}^{2} \cdot \mathrm{K}\right)\right]$ was evaluated for the analysed solutions of the corners [6]:

- calculation of the value of the mean horizontal component of heat flux density for the part of joint $q_{1}$ and $q_{2}\left[\mathrm{~W} / \mathrm{m}^{2}\right]$,

- calculation of the thermal transmittance based on:

$U_{1}=q_{1} /\left(t_{\mathrm{i}}-t_{\mathrm{e}}\right)\left[\mathrm{W} /\left(\mathrm{m}^{2} \mathrm{~K}\right)\right]$,

$U_{2}=q_{2} /\left(t_{\mathrm{i}}-t_{\mathrm{e}}\right)\left[\mathrm{W} /\left(\mathrm{m}^{2} \mathrm{~K}\right)\right]$,

where:

$q_{1}, q_{2}$ - heat flux density, [W/m $\left.{ }^{2}\right]$,

$t_{\mathrm{i},} t_{\mathrm{e}} \quad$ - internal and external temperature.

Based on [7], the internal temperature was adopted as $t_{\mathrm{i}}=+20^{\circ} \mathrm{C}$ whereas according to [8], the design external temperature was $t_{\mathrm{e}}=-20^{\circ} \mathrm{C}$. Thermal transfer coefficients on the internal side used in the FEM analysis were adopted for the horizontal flow as $h_{\mathrm{i}}=7.69 \mathrm{~W} /\left(\mathrm{m}^{2} \cdot \mathrm{K}\right)$ on the internal side and $h_{\mathrm{e}}=25 \mathrm{~W} /\left(\mathrm{m}^{2} \cdot \mathrm{K}\right)$ on the external side, representing the reversed value of the resistances $R_{\mathrm{si}}, R_{\mathrm{se}}$, $[9,10]$. The boundary conditions for calculations of minimal temperature on the internal side of the wall $t_{\min }\left[{ }^{\circ} \mathrm{C}\right]$ and the temperature factor $f_{\mathrm{Rsi}}[-]$ are used according to [11]. They amount to $R_{\mathrm{si}}=0.25$ $\left(\mathrm{m}^{2} \cdot \mathrm{K}\right) / \mathrm{W}$.

Numerical analysis was made using the ANSYS software based on the finite elements method [12 - 16]. The analysis was performed for the assumption of homogeneity and isotropy of materials of individual layers. 


\section{Analytical and numerical results}

During calculation of the linear transmittance coefficient $\psi[\mathrm{W} /(\mathrm{m} \cdot \mathrm{K})]$, the height of the corner was adopted as $l_{\mathrm{i}}=1 \mathrm{~m}$. Therefore, after calculation of the value of linear thermal transmittance coefficient, its value can be multiplied by the thermal bridge length.

Heat flux $\Phi[\mathrm{W}]$ for the heat flowing through the joint was calculated using numerical methods, see Table 1. Next, analytical calculations were used to determine other thermal and humidity parameters, see Table 1.

The branch linear thermal transmittance coefficient for the joint surface $\psi_{\mathrm{e}}\left[\mathrm{W} /\left(\mathrm{m}^{2} \cdot \mathrm{K}\right)\right]$ was obtained from (3) for the external dimensions $l_{\mathrm{e}}[\mathrm{m}]$.

$\psi_{\mathrm{e}}=L^{2 \mathrm{D}}-\left(l_{\mathrm{e} 1} \cdot U_{1}-l_{\mathrm{e} 2} \cdot U_{2}\right)\left[\mathrm{W} /\left(\mathrm{m}^{2} \cdot \mathrm{K}\right)\right]$,

where:

$L^{2 \mathrm{D}}$ - linear coefficient of thermal coupling of the joint $[\mathrm{W} /(\mathrm{m} \cdot \mathrm{K})]$,

$U_{1}, U_{2}$ - thermal transmittance coefficients for individual parts of the joint $\left[\mathrm{W} /\left(\mathrm{m}^{2} \cdot \mathrm{K}\right)\right]$,

$l_{\mathrm{e} 1}, l_{\mathrm{e} 2}$ - length of the linear bridge at the external side, $\left(l_{\mathrm{e} 1}=1.543 \mathrm{~m}, l_{\mathrm{e} 2}=1.415 \mathrm{~m}\right)$.

Linear coefficient of the coupling $L^{2 \mathrm{D}}[\mathrm{W} /(\mathrm{m} \cdot \mathrm{K})]$ between the two environments was calculated from the relationship:

$L^{2 \mathrm{D}}=\frac{\Phi}{l_{\mathrm{i}}\left(t_{\mathrm{i}}-t_{\mathrm{B}}\right)}[\mathrm{W} /(\mathrm{m} \cdot \mathrm{K})]$.

Apart from thermal parameter, the humidity profile was determined for the analysed thermal bridges according to [11]. Numerical calculations were made to obtain minimal temperatures $t_{\min }$ on the internal surface of the thermal bridge partition. Minimal temperature is $t_{\min }=16.81^{\circ} \mathrm{C}$ for the wall with the wood framing and $t_{\min }=17.09{ }^{\circ} \mathrm{C}$ for the steel framing. Next, temperature conditions of $f_{\mathrm{Rsi}}$ were obtained based on:

$f_{\mathrm{Rsi}, \mathrm{obl}}=\frac{t_{\mathrm{si}, \mathrm{min}}-t_{\mathrm{e}}}{t_{\mathrm{i}}-t_{\mathrm{E}}}$

where:

$t_{\mathrm{si}, \text { min }}$ - minimal temperature on the internal surface of the thermal bridge partition $\left[{ }^{\circ} \mathrm{C}\right]$,

$t_{\mathrm{e}}$ - ambient air temperature $\left[{ }^{\circ} \mathrm{C}\right]$,

$t_{\mathrm{i}}$ - internal air temperature $\left[{ }^{\circ} \mathrm{C}\right]$.

The temperature factor was $f_{\mathrm{Rsi}, \mathrm{obl}}=0.92$ for the wood framing and $f_{\mathrm{Rsi}, \mathrm{obl}}=0.93$ for the steel framing. According to [7], required critical value of the temperature factor $f_{\mathrm{Rsi}, \mathrm{kryt}}$ is 0.72 . As can be noticed, the values of $f_{\mathrm{Rsi}, \text { obl }}$ for the analysed joints are greater than the critical value $f_{\mathrm{Rsi}, k r y t}$. Therefore, there is no risk of condensation on the internal surface of the wall.

Table 1: Heat parameters of the analyzed external partitions.

\begin{tabular}{|c|l|c|c|}
\hline \multirow{2}{*}{ Characteristic thermal parameters of the corner of the outer wall } & \multirow{2}{*}{ Values } \\
\hline \multirow{2}{*}{1} & \multirow{2}{*}{ Total heat flux $\varphi[\mathrm{W}]$ flowing through the joint } & Wood framing & 11.073 \\
\cline { 3 - 4 } & & Steel framing & 11.768 \\
\hline \multirow{2}{*}{2} & Thermal transmittance coefficients $U\left[\mathrm{~W} /\left(\mathrm{m}^{2} \cdot \mathrm{K}\right)\right]$ & Wood framing & 0.126 \\
\cline { 3 - 4 } & for individual parts of the joint & Steel framing & 0.124 \\
\hline \multirow{2}{*}{3} & Linear coefficient of thermal coupling $L^{2 \mathrm{D}}[\mathrm{W} /(\mathrm{m} \cdot \mathrm{K})]$ & Wood framing & 0.277 \\
\cline { 3 - 4 } & & Steel framing & 0.294 \\
\hline \multirow{2}{*}{4} & Linear thermal transmittance coefficient $($ for the & Wood framing & -0.096 \\
\cline { 3 - 4 } & external dimensions $) \psi_{\mathrm{e}}[\mathrm{W} /(\mathrm{m} \cdot \mathrm{K})]$ & Steel framing & -0.073 \\
\hline \multirow{2}{*}{5} & Temperature factor $f_{\mathrm{Rsi}, o b l}$ & Wood framing & 0.92 \\
\cline { 3 - 4 } & & Steel framing & 0.93 \\
\hline
\end{tabular}


Figs. $2 \div 5$ illustrate distribution of temperature and heat flux density. For the partition with steel framing, substantial disturbances can be observed in the locations of their fixation concerning both distribution of temperature and heat flux density (Figs. 4 and 5). This is attributable mainly to a high thermal transmittance coefficient $\lambda[\mathrm{W} /(\mathrm{m} \cdot \mathrm{K})]$ of the sections. A spot decline in temperature can be observed in the corner of this structure, with temperature of $14.091{ }^{\circ} \mathrm{C}$, see Fig. $4 \mathrm{a}$. This can be caused by the contact of both sections in this place.

a)

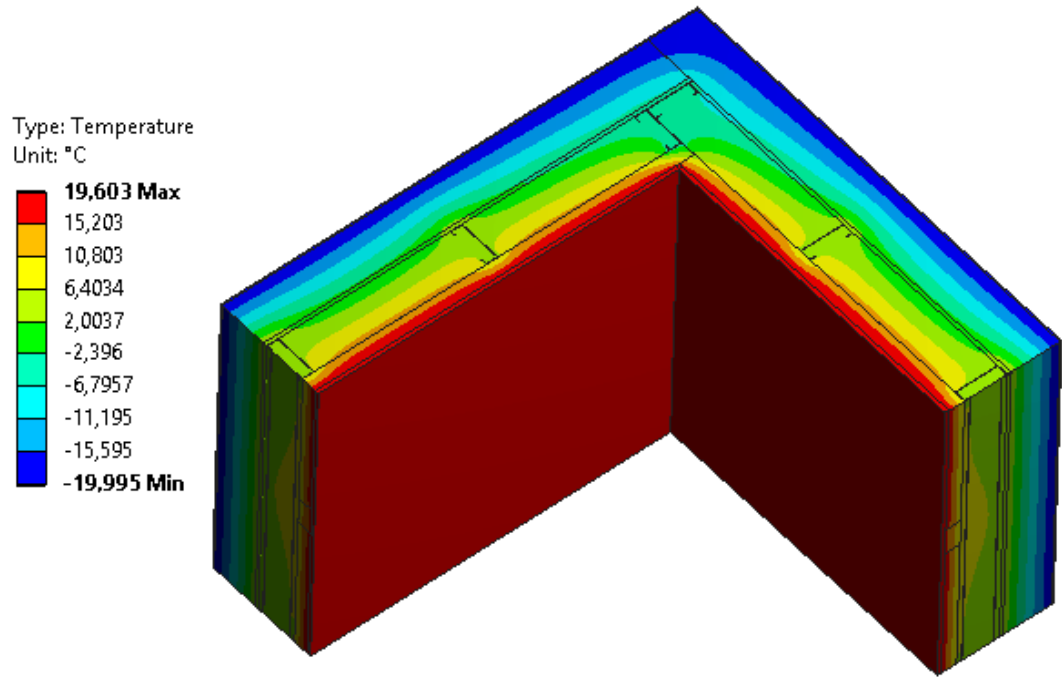

b)

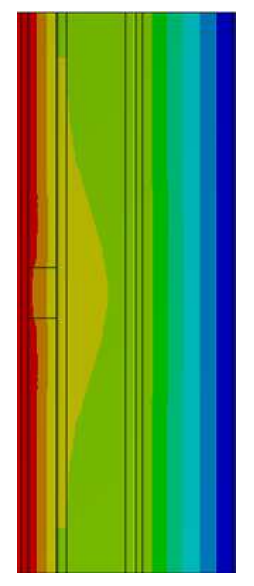

Fig. 2: Distribution of temperature for wood framing: a) 3D view, b) distribution in the framing crosssection.

a)

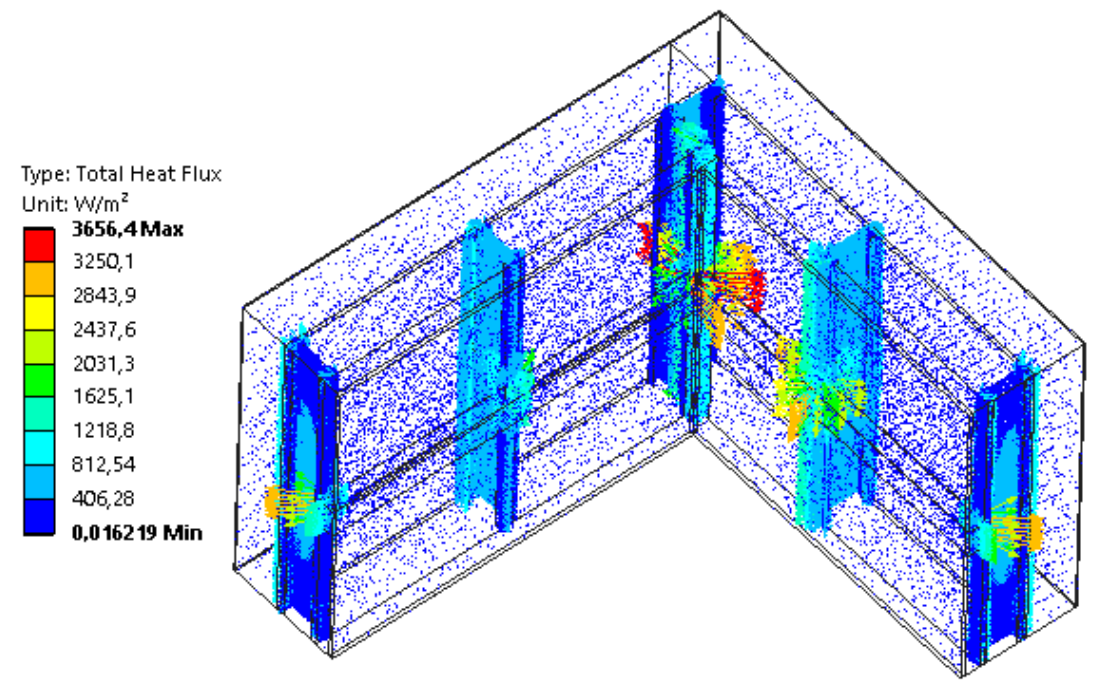

b)

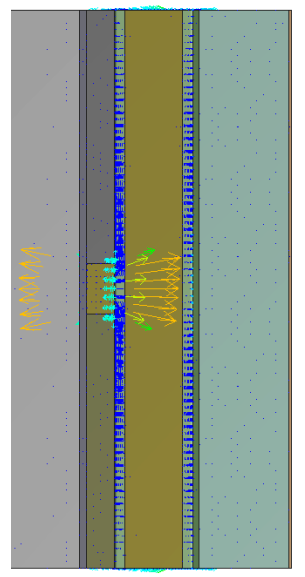

Fig. 3: Distribution of heat flux density for wood framing: a) 3D view, b) distribution in the framing cross-section. 
a)

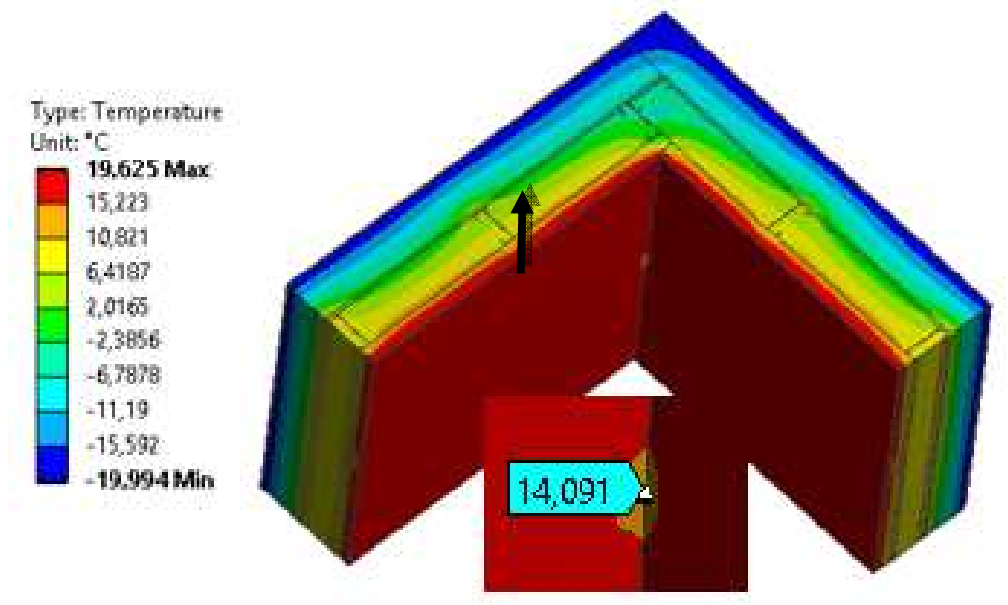

b)

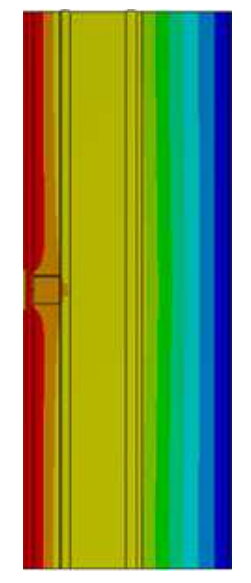

Fig. 4: Distribution of temperature for steel framing: a) 3D view, b) distribution in the framing crosssection.

a)

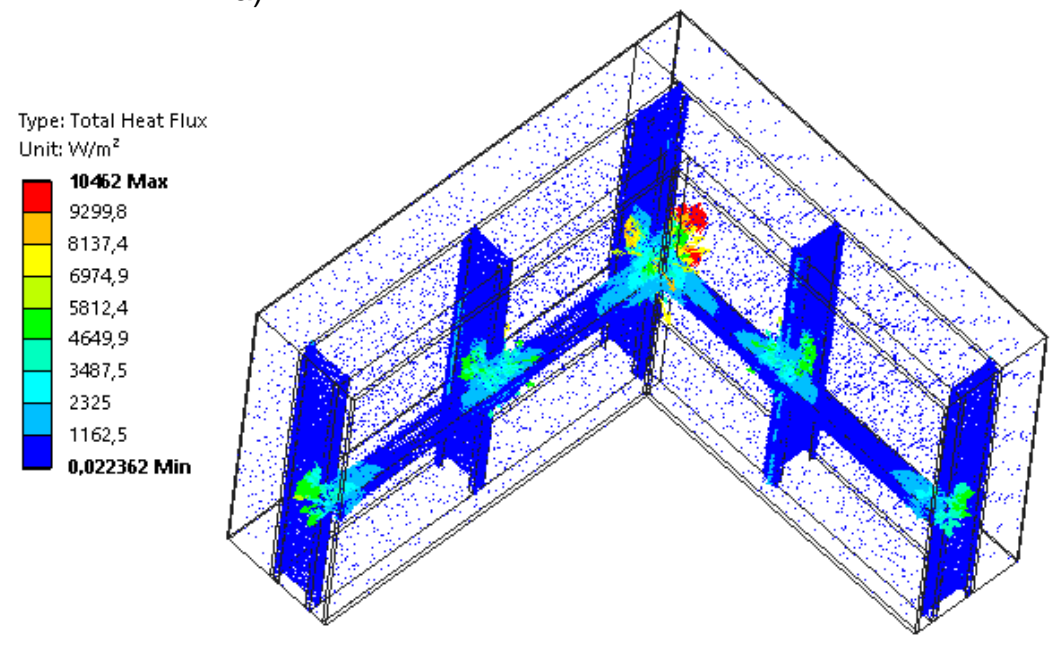

b)

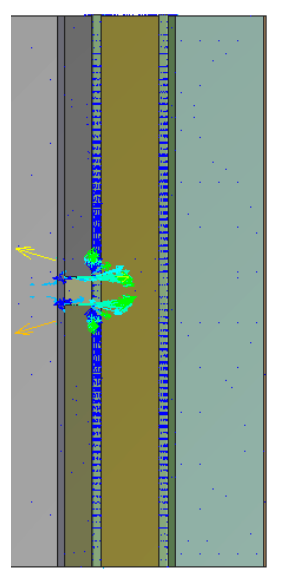

Fig. 5: Distribution of heat flux density for steel framing: a) 3D view, b) distribution in the framing crosssection.

\section{Conclusions}

The analysis demonstrated differences in thermal and humidity parameters of the framing components used for securing drywall panels. Better parameters were found for the structure made of wood studs. For example, the difference in the linear thermal bridge is $23 \%$, with higher values obtained for wood framing. In the case of the temperature factor $f_{\text {Rsiobl, }}$, the requirements made by [7] for both sections are met at insignificant difference between each other.

Despite better thermal and humidity parameters of wood framing, steel framing is much more popular. This is caused, among other things, by poor availability of high-quality and well-processed wood and the fact that building warehouses offer a greater choice of steel sections.

In the areas of thermal bridges, designers should strive for limitation of their negative impact on heat loss and risk of condensation. The particular focus should be paid to proper design of the material systems in the joint and preventing from the gaps formed between thermal insulation and structural components [1].

There are many methods for determining the thermal and humidity parameters of materials and buildings [17, 18]. The analysis presented in this study confirms the usefulness of numerical computational software based on the FEM methodology. For example, they can be used to analyse technological and constructional solutions at the design stage which are especially important for the functional properties of the building. 


\section{References}

[1] MAJOR, I.: Technologia budowy domów szkieletowych - ekologiczna forma jednorodzinnego budownictwa mieszkaniowego (Home frame construction technology - ecological form of singlefamily housing). Jakościowe i ekologiczne aspekty w technologiach budowlanych, ed. Ulewicz, M., Selejdak, J., Monografia, Częstochowa 2013, pp. 86-102 (in Polish).

[2] SANTOS, P.- MARTINS, C. - Da SILVA, L. S. - BRAGANCA, L.: Thermal performance of lightweight steel framed wall: The importance of flanking thermal losses. Journal of Building Physics, Vol. 38, Iss.1, July 2014, pp. 81-98, https://doi.org/10.1177/1744259113499212.

[3] ROQUE, E. - SANTOS, P.: The effectiveness of thermal insulation in lightweight steel-framed walls with respect to its position. Buildings, Vol. 7, Iss.1, 2017, doi: 10.3390/buildings7010013.

[4] KOŁODZIEJCZYK, S.: Fizyka konstrukcji budowlanych (The physics of building construction). PWN, Łódź 1962 (in Polish).

[5] BOGOSŁAWSKI, W. N.: Procesy cieplno - wilgotnosciowe w budynkach (Thermal-humidity processes in buildings). Arkady, Warszawa 1985 (in Polish).

[6] GOŁAŚ, A. - RYŚ, M. - GAJDA, R.: Badanie własności termoizolacyjnych okien z wykorzystaniem metody elementów skończonych (Investigation of heat insulating properties of windows using the finite element method). Modelowanie Inżynierskie, Gliwice 2011 (in Polish).

[7] Rozporządzenie Ministra Infrastruktury z dnia 12 kwietnia 2002 r. w sprawie warunków technicznych, jakim powinny odpowiadać budynki i ich usytuowanie, Dz.U. z 2002 r., Nr 75, poz. 690 (in Polish).

[8] PN-EN 12831:2006. Instalacje ogrzewcze w budynkach - Metoda obliczania projektowego obciążenia cieplnego (in Polish).

[9] PAWŁOWSKI, K.: Projektowanie przegród zewnętrznych w świetle aktualnych warunków technicznych dotyczących budynków (The design of external barriers in the light of current technical requirements for buildings). Grupa Medium, Warszawa 2016 (in Polish).

[10] PN-EN ISO 6946:2008 Komponenty budowlane i elementy budynku - Opór cieplny i współczynnik przenikania ciepła - Metoda obliczania (in Polish).

[11] PN-EN ISO 13788:2003 Cieplno - wilgotnościowe właściwości komponentów budowlanych i elementów budynku. Temperatura powierzchni wewnętrznej umożliwiająca uniknięcie krytycznej wilgotności powierzchni wewnętrznej kondensacji. Metody obliczania (in Polish).

[12] ANSYS Mechanical APDL Thermal Analysis Guide. 2013.

[13] MADENCI, E. - GUVEN, I.: The finite element method and applications in engineering using ANSYS $\AA$, Springer, 2007.

[14] MAJOR, M. - KOSIŃ, M.: Modelowanie rozkładu temperatur w przegrodach zewnętrznych wykonanych z użyciem lekkich konstrukcji stalowych (Modeling of temperature distribution in external building barriers constructed as lightweight framing systems). Budownictwo 0 zoptymalizowanym potencjale energetycznym, Częstochowa 2016 (in Polish).

[15] LI, A. - XU, X. - XIE, J.- SUN, Y.: Development of a simplified heat transfer model of hollow blocks by using finite element method in frequency domain. Energy and Buildings, Vol.111, 2016, pp. 76-86.

[16] ZHANG, Z.P - S. ZHU, W. - CHEN, G. P.: Study on thermal performance for straw fiber concrete hollow block. Advanced Materials Research, Vol. 953-954, 2014, pp.1596-1599, doi: 10.4028/www.scientific.net/AMR.953-954.1596.

[17] PETKOVA-SLIPETS, R. - ZLATEVA, P.: Thermal insulating properties of straw-filled environmentally friendly building materials. Civil and Environmental Engineering, Vol.13, Iss. 1/2017, pp. 52-57, https://doi.org/10.1515/cee-2017-0006.

[18] MAJEWSKI, G. - TELEJKO, M. - ORMAN, Ł. J.: Analysis of thermal comfort in an intelligent building. Civil and Environmental Engineering, Vol. 13, Iss. 1/2017, pp. 72-76, https://doi.org/10.1515/cee-2017-0009. 